AN EXAMINATION OF INTERNATIONAL RETAIL FRANCHISING IN EMERGING MARKETS

By: Dianne H.B. Welsh ${ }^{1}$, Ilan Alon ${ }^{2}$, and Cecilia M. Falbe ${ }^{3}$

Welsh, D.H.B., Alon, I., \& Falbe, C.M. (2006, January). An examination of international retail franchising in emerging markets. Journal of Small Business Management, 44(1), 130-149.

Made available courtesy of BLACKWELL PUBLISHING LTD.

The definitive version is available at www.blackwell-synergy.com

\begin{abstract}
:
There has been an urgent call from both the franchise industry, as well as the academic community, for research on world franchising markets, specifically in the retail sector. This article is an attempt to summarize the main research that has been conducted thus far on international retail franchising. The article begins with an overview of the development of the literature and discusses the nature and scope of emerging markets, with particular reference to their impact on the stakeholders of international retail franchising. Next, the article develops a conceptual model relating international retail franchising to its stakeholders. Then, a review of the research is divided into areas of the emerging world market: Central and Eastern Europe, Mexico and South America, Asia, and other areas that include India, Kuwait, and South Africa. The article concludes by discussing the next step to developing a research base and understanding of emerging markets in addition to the opportunities and challenges for retail franchising, and future research.
\end{abstract}

\footnotetext{
${ }^{1}$ Dianne Welsh is the James W. Walter Distinguished Chair in Entrepreneurship, Professor of Management, and Director of the Entrepreneurship \& Family Business Programs at the University of Tampa. She is the 2005 President of the U.S. Assn. for Small Business \& Entrepreneurship (USASBE) and is on the Executive Boards for the Entrepreneurship Division of the Academy of Management and the National Consortium of Entrepreneurship Center Director's Assn.

${ }^{2}$ Illan Alon is Director of Global Consulting Projects and Associate Professor of International Business at the Crummer Graduate School of Business at Rollins College. He is the author/editor of 10 books and over 100 published manuscripts relating to franchising, China, and business education.

${ }^{3}$ Cecilia M. Falbe is Associate Professor, Department of Management, School of Business and faculty member of the Organizational Studies Doctoral Program, University at Albany-State University of New York. Her research interests include franchising, new venture creation, and strategic change.
} 


\title{
An Examination of International Retail Franchising in Emerging Markets
}

\author{
by Dianne H.B. Welsh, Ilan Alon, and Cecilia M. Falbe
}

Abstract

There has been an urgent call from both the franchise industry, as well as the academic community, for research on world franchising markets, specifically in the retail sector. This article is an attempt to summarize the main research that has been conducted thus far on international retail franchising. The article begins with an overview of the development of the literature and discusses the nature and scope of emerging markets, with particular reference to their impact on the stakeholders of international retail franchising. Next, the article develops a conceptual model relating international retail franchising to its stakeholders. Then, a review of the research is divided into areas of the emerging world market: Central and Eastern Europe, Mexico and South America, Asia, and other areas that include India, Kuwait, and South Africa. The article concludes by discussing the next step to developing a research base and understanding of emerging markets in addition to the opportunities and challenges for retail franchising, and future research. 


\section{Introduction}

Explaining the phenomenal growth of retail franchising in the United States and the United Kingdom has been a major focus in the academic franchising literature over the past three decades. US franchising sales increased approximately 94 percent from 1983 to 1993 (Preble and Hoffman 1994). Figures vary, but it is estimated that U.S. franchising generates $\$ 800$ billion worth of business in gross sales and represents 40 percent of the retail trade (Swartz 2001). According to Shane and Spell (1998), retail franchising "has become the dominant mode of retail entrepreneurship in the United States." Retail franchising is an important and growing component of the United Kingdom economy as well (Boyle 1999). The number of franchising systems in the UK increased by 30 percent between 1994 and 1997 (Boyle 1999). Clarke (1997) estimated that if franchising was considered in its broader context to include tenanted pubs, petrol stations, car dealerships, and soft drink bottlers, the total annual franchise sales in Britain would be worth 33.3 billion pounds and make up around 19 percent of all retail sales in the UK (Boyle 1999).

In the US, Canada, and parts of Western Europe, retail franchising has reached domestic market saturation, while emerging markets remain relatively untapped. Retail franchises have been established in these markets primarily in the last 15 years through master franchises and corporate franchise agreements, and to a lesser extent, joint venture franchising and conversion franchising (Alon and McKee 1999; Connell 1999; Doherty and Quinn 1999; Hadjimarcou and Barnes 1998; Hoffman and Preble, 2003). Emerging markets, which account for 
80 percent of the world's population and 60 percent of the world's natural resources, present the most dynamic potential for long-term growth to businesses, in general, and to franchisors, specifically. The US Department of Commerce estimated that over 75 percent of the expected growth in world trade over the next two decades will come from emerging countries, particularly Big Emerging Countries, which account for over half the world's population but only 25 percent of its GDP.

Emerging markets are among the fastest growing targets for investment by international franchisors. Several surveys conducted by industry experts showed that more and more franchisors are seeking opportunities in these markets. A recent article in Franchising World stated, "Franchises are springing up in the most unlikely, and for many of us unheard-of, places... Those franchisors who can establish a beachhead on these wilder shores could do very well, but the risks are great" (Amies 1999, pp. 27-28).

A number of authors, both industry analysts and academics, have identified emerging markets as a topic that needs further research (Kaufmann and Leibenstein 1988). Researchers responded to this call. Welsh (1990) conducted the first survey on franchising in Russia, at the time McDonalds opened its first franchise in Moscow to a tremendous welcoming by the Russian people and press. An empirical study was subsequently published (Welsh and Swerdlow 1991). Since the 1980s, franchising in emerging markets has grown dramatically. For example, by 1995, there were 26 more franchisors in Brazil alone than there were in all of South America in 1985 (International Franchise Research Centre 
2000). By 1997 , the top 50 US food chains had $\$ 33.1$ billion in international sales due to the significant efforts s by large US-based food retail franchisors (Breuhaus 1998).

The recent acceleration of franchising in emerging markets is now receiving greater attention in both the academic and practitioner literature. However, this literature is widely dispersed and, in some cases, challenging to access. The first purpose of this paper is to provide a review and summary of the literature on retail franchising in emerging markets. In addition to the traditional literature searches generally targeted to the leading journals, we also accessed franchise-specific sources of information that have limited circulation among the academic public. The review includes journal articles, all of the Proceedings of the International Society of Franchising from the initial publication in 1986 to 2002, contributions from Franchising Research: An International Journal, as well as articles in recently published books on international franchising in emerging markets. This paper integrates the research that has been conducted in emerging economies in order to help understand international retail franchising opportunities and threats in emerging economies in the hope of expanding the research in this area in the future, as well as assisting the retail franchise industry.

The second purpose of this paper is to present a conceptual model of the stakeholders of international retail franchising including consumers, franchisees, franchisors, host country markets and home country markets. The model provides a means of examining the benefits/costs of international business format 
franchising from the perspective of the stakeholders and examines the impact of these complex relationships on developments in international franchising.

We begin with a brief overview of the development of the literature and a discussion of the characteristics of emerging markets. The article then presents a model of stakeholder relations in franchising and links the stakeholder approach to concepts of international retail franchising. We conclude with a review of the research on area markets and offer suggestions for future research.

\section{An Overview of the Literature}

Early studies of franchising were linked to the classic argument that economic organization follows two general forms, markets and firms (Coase 1937). Theorists identified franchising as a hybrid manifestation of the two forms since it included both market-like and firm-like qualities (Brickley and Dark 1987; Norton 1988; Rubin 1978; Mathewson and Winter 1985). Franchising is seen as a means of obtaining scarce capital as the franchisee is generally required to make a substantial investment in the business. Franchisees share risk with the franchisor. Franchising is also identified as a way of addressing the agency problem, specifically, the issue of monitoring managers (Brickley and Dark 1987; Mathewson and Winter 1985). Franchisees with substantial investments are more motivated to maximize revenues through administrative efficiency and protection of the franchise brand while minimizing operational costs.

These earlier arguments apply to franchising in emerging markets which offer even greater challenges in the areas of monitoring, resource scarcity, and 
risk reduction. The issues of monitoring and risk are greatly increased in international franchising by both geographical and cultural distance (FladmoreLinquist and Jacque 1995). The stakeholder model highlights the location of potential problems in monitoring and risk.

Useful reviews of the literature on international franchising were published by Elango and Fried (1997) and Young, McIntyre and Green (2000). In their survey of franchising research published in journals, Elango and Fried discovered that "the manner in which franchise systems work to create value had been ignored" (76). They cited a lack of franchising case studies as contributing to this problem. Their point is especially applicable for international retail franchising and distribution systems worldwide. Young, McIntyre, and Green examined the content of articles that were published in the International Society of Franchising Proceedings. Out of approximately 70 articles published between 1987 and 1999, nine dealt with economies in transition and 14 others dealt with developing economies. The authors include a useful table that arranges international franchise articles by country/region.

Hadjimarcou and Barnes (1998) found that international retail franchise expansion is not just done by the largest franchises, but by all kinds of franchisors that see international retail expansion as a profitable venture and logical extension of their home operations. For example, some well-known UK retailers, including the Body Shop, Benetton, and Motehrcare, have used franchising as the hallmark of their international activity (Doherty and Quinn 1999). 
In The Internationalization of U.S. Franchising Systems, Alon (1999)

provides a comprehensive review of the international retail franchising literature and classifies the theories of international franchising into two research streams one focuses on environmental variables, and the second focuses on organizational capabilities of the franchisor. Such theories include the seminal works of Hackett (1976) and Welch (1989). Hackett (1976) was one of the first franchising researchers to point out the trend of domestic market saturation in the franchising sector that has forced franchisors to seek alternate markets, especially abroad. Welch (1989) proposed that franchising follows a life-cycle that begins with internationalization into industrial markets similar to the US (such as Canada, the UK, and Australia), continues into dissimilar developed markets (such as Japan), and progresses into emerging markets that are culturally distinct and economically less developed. The cycle ends with franchisors from the latter countries entering the original home markets to compete with the founders of the concept.

Although academics and practitioners are beginning to answer the call for more research and evaluation of retail franchising in these new markets around the globe; it is clear that coverage is incomplete and additional research is needed.

\section{Characteristics of Emerging Markets}

While there is no consensus on the definition of the term "emerging market," Czinkota and Ronkainen (1997) identified three characteristics associated with an 
emerging economy: level of economic development, economic growth and market governance.

\section{Level of Economic Development}

The level of economic development is typically measured in terms of GDP per capita. GDP per capita is a useful measure of economic development because it is related to the population's wealth, extent of middle class, and level of industrial and service sector development (Alon and McKee 1999).

The usage of the level of economic development as a demarcation criterion for distinguishing emerging markets equates with the anachronisms of the World Bank and the United Nations, which include terms such as Less Developed Countries (LDC's), Third World Countries, and Developing Countries. The World Bank divides countries on the basis of GDP per capita into four classes. Three of the Big Emerging Countries (India, China, and Vietnam) fall into the lowest income class, but have seen a surge of growth in recent years particularly in the technology sector. According to the United Nations, only about 15 percent of the world's population reside in developed market economy countries (Czinkota and Ronkainen 1997). When considering an emerging market, it is important to adjust GDP per capita to purchasing power parity in order to gauge income in relation to the "real" cost of living.

\section{Economic Growth}


Economic growth is usually measured in terms of the country's GDP growth rate. The usage of economic growth is consistent with the concept of "emerging." Most of the countries referred to as emerging markets have enjoyed GDP growth rates exceeding five percent from 1990 to 1997, with some markets, particularly in East Asia, displaying double-digit growth rates (Czinkota and Ronkainen 1997). In 1997, 1998, and 1999, East Asia, Brazil, and Russia encountered financial crises that set back their economies' growth. Such crises demonstrate that the often-touted high growth rates of emerging markets may not be sustainable over a long period of time.

The level of economic growth is among the most important considerations for international franchising expansion (Alon and McKee 1999). When examining an emerging market's GDP growth, one must contrast it to the growth in the population. If population growth rates exceed GDP growth rates, then the standard of living in those countries will actually drop over time. The most useful measure that captures both growth rates is GDP per capita growth rate.

\section{Market Governance}

The third criteria for judging emerging markets is the country's market governance. Market governance includes the level of free market activity, government control of key resources, stability of the market system and the regulatory environment. Countries that are liberalizing their economic institutions and democratizing their political structures are often referred to as Transitional Economies/Countries. These transitions have been welcomed by the western 
economies and regarded as opportunities for international retail franchising expansion.

Among the most important transitional elements with respect to international investors are the political and economic risks that are introduced by the reorganization of economic and political units in emerging marketplaces (Czinkota and Ronkainen 1997). Such risks are systematically evaluated by western institutions such as the Economist Intelligence Unit, Institutional Investor, and International Country Risk Guide (The ICRG is a business-venture risk rating system, whereby a number value is attached to a foreign country by an independent collaborative group after many determining factors are evaluated and weighed).

Market governance influences a wide range of country risk elements such as government regulation and red tape, political stability, bribery, ownership restrictions, controls of capital flows and import restrictions. All these factors are important to international franchisors' evaluations of foreign market potential and essential to determinations of franchise expansion in the international retail arena (Alon and McKee 1999).

\section{A Stakeholder Model of International Franchising}

The stakeholder approach to management views the consumer holistically within the context of the environment. The company must take into account not only the shareholders and ultimate consumers, but also any group directly or indirectly affected by the firm's business maneuvers. The general public, for 
instance, may be interested in how the foreign company might promote or defeat the country's economic goals, or simply might inquire how much pollution is incurred. In either case, the company's decisions affect the public welfare, and possibly individual rights, and therefore, a prudent corporation exploring new borders should attempt to take into account all possible scenarios, or may suffer irreparable consequences.

Hence, this article proposes the stakeholder model which illustrates international retail franchising in emerging markets from the viewpoint of the franchisor, franchisee, host market, home market and consumer. The perspective focuses on the key stakeholders of international retail franchising in emerging markets and discusses how they relate to each other according to current research on international retail franchising.

\section{Insert Figure 1 about here: included separately in a power point slide}

\section{Franchisors}

Emerging markets offer a number of advantages to franchisors. They include, but are not limited to, an expanding middle class necessary for retail franchising to excel, relatively unsaturated markets, urbanized and highly populated cities for the most part, a growing youth market, free trade zones, relatively friendly business laws, liberalized markets and transitioning economies, and a huge pent-up demand for western-style goods and services. 
In emerging markets, retail franchising allows companies to expand consumer offerings in geographical markets with relatively minimal financial investment and risk. Local franchisee ownership not only promotes political and cultural acceptability, but also decreases some of the negativity surrounding the purchasing of products not produced in the home country. In addition, it lowers much of the political risk surrounding foreign investment. The franchisor has the opportunity to acquire a broad base of knowledge concerning local customs and market conditions, economic networks, political affiliations, and industry experience of the franchise partner, which can greatly enhance the possibility of success for both the franchisor and franchisee(s). Brand-name recognition and customer loyalty is greatly enhanced through standardized customer service that leads to shared long-term success.

Stanworth, Price, and Purdy (2001) summarized the advantages of global franchising to the franchisor as fewer financial resources required, raw materials can be produced internally, less susceptibility to political, economic, and cultural risks, and franchises are more familiar with local laws, language, culture, business norms and practices. Risks to the franchisor included possible difficulties in repatriating royalties, protecting copyright and intellectual property, policing quality standards, understanding laws, regulations, language and business norms, servicing franchisees, and terminating contracts and local imitations.

One downside of franchising in emerging markets from the perspective of the franchisor is the capital controls that may inhibit repatriation of fees and royalties which effectively may drastically reduce the economic benefits of the 
investment. Legal constraints, bureaucratic conditions, changes in the legal environment, unstable political leadership, limited infrastructure, sporadic enforcement of established laws, particularly in regards to business ownership and operations, all have the effect of impeding international franchise expansion. In the area of intellectual property, legally protecting international copyrights, trademarks, and patents is difficult and expensive. Another perceived challenge involves the continuous training, monitoring, and controlling of international franchisees. This is exacerbated by differences in cultures that affect the franchisor-franchisee relationship.

\section{Franchisees}

The emerging market franchisee benefits from ongoing support in terms of periodic system-wide programs and promotions, new product innovations and development, superior market research, and advice. In some instances, because of the differences in host-country environment, various experiences of the franchisor may not be transferable from one country to another. This is particularly evident by the numerous examples of false starts and restarts that franchisors have made in some emerging markets. Overall, the chances of succeeding are greatly increased by the globalization of consumer markets and the past successes in reproducing the business format in heterogeneous locations around the globe.

Kaufmann and Liebenstein (1988) discussed fringe franchisors that are not reputable. Although theory and research is based on the assumption that the franchisor is a respectable sound company with a proven concept, format and 
history of support, this is not always true. Kaufmann and Leibenstein reiterate that disclosure statements are a must for governments to require when a retail franchise enters the country and the importance of such documentation to reduce a franchisee's risk.

\section{Master Franchisees}

Indirect franchising, that is, use of a master franchisee to develop a territory or a whole country is a common strategy employed by franchisors in emerging markets. Nair (2001) noted that the advantages of this system include access to resources, knowledge of the local market, more adaptation and the possibility of developing a successful franchise as a tool for selling to prospective franchisees. The indirect system also has disadvantages, including lower profits for franchisors and franchisees, and monitoring issues because of loss of control. There have been numerous examples of a master franchisee holding the subfranchisees hostage to compete against the franchisor. Ultimately, success will be determined by the energy, capabilities and resources of the master franchisee.

\section{Franchisor / Franchisee Relationships}

New symbiotic relationships are created when retail franchising expands into developing countries. Retail franchising allows firms to achieve the expanded reach and efficiencies associated with internationalization more rapidly and effectively than the firms could accomplish on their own. Dana, Etemad and Wright (2001) developed an Interdependence Paradigm to explain these franchise 
marketing networks using examples of firms in South Korea and the Philippines. In their paradigm, franchising involves a network of franchisees under the guidance of a parent firm, the franchisor. Franchisors that are well established can achieve greater efficiencies by incorporating smaller franchisees from emerging markets into international franchise networks. Importantly, the authors point out that franchising can help overcome local ownership requirements in regulated sectors. Therefore, franchising enhances the competitiveness of franchisors, while contributing to the development of emerging markets. A "symbiotic interdependence" forms between franchisors and franchisees in a network. Dana, Etemad and Wright (2001) view the consequences of this paradigm shift from independence to interdependence to be far reaching and having a major impact on the way business is handled internationally.

\section{Host-Home Country Markets and Influences}

Franchising in emerging markets also offers the host countries certain advantages. These benefits include obtaining foreign currency with little capital outlay, increases in employment, and thereby, growth in the franchisor's tax-base and gross domestic output. Also, franchise growth and development spawn entrepreneurial development comprised of small and medium enterprise networks. Certainly, "home grown" franchises are more likely to develop. There is a resulting increase in the knowledge base of the business population concerning product distribution, market management, and western-style marketing techniques, all of which increase the skill base of local labor. There are 
increasing efficiencies that result from innovation and rationalization in all sectors of the economy-retail, wholesale, and manufacturing. This leads to further development of the host country's infrastructure, particularly in the areas of transportation and supplies. Alon (2004) examined the macro-environmental impacts of franchising on the host and home markets and included in his analyses economic, political and social ramifications, both positive and negative. $\mathrm{He}$ concluded that the probable overall impact, however, is positive in the long term.

Governments have increasingly become aware of the benefits to their country that franchising has to offer. As a result, many governments are in the process of improving their country's business environment to attract high quality franchises. The improvements have included positive legislation for franchise regulations, establishing support organizations, trade associations and franchise education programs. In many cases, foreign governments have funded programs to encourage economic development through retail franchising in emerging economies, such as the USAID Programs in the former Russian Republics.

On the other hand, retail franchising may have adverse effects on the host market. Retail franchising can sometimes supplant traditional and local cultural elements, which over time can lead to homogenization and westernization of preferences, especially among the youth population. The older generations and the political establishments often resist such cultural shifts.

International retail franchising oftentimes has the effect of displacing local industry, particularly "mom-and-pop" stores. These stores can not effectively compete with the distribution and marketing expertise of multinational 
franchisors. At the national level, franchising can negatively influence the host country's balance of payments over time because of the repatriation of fees and royalties by the franchisor.

\section{Global Consumers}

Overall, franchising worldwide has had the effect of offering consumers lower prices through efficient distribution of goods and services, and consistent quality through standardization. This has been particularly true with the expansion of retail franchising. It is questionable that without retail franchising if these two areas, higher quality and lower prices (that is, consumer value) would have improved at the rate that they have throughout the world market.

The efficiencies from the technological and digital revolution will probably lower costs even more for consumers. Increased retail franchising in the developing world will provide the data necessary for researchers and the host country government to determine the impact of retail franchising on economic development. Such empirical research is badly needed.

\section{A Model of International Retail Franchising}

\section{Model Development}

There are two major models that have been developed in the area of retail franchising. In the first, Alon (1999) developed and tested a model of international franchising based on the literature of agency and resource-based theories that utilizes organizational characteristics - size, age growth, rate, fees, and royalties, combined with physical dispersion - to explain the 
internationalization of US franchisors. The second approach examined marketing through a modular system as the standardization of the core elements ('absolutely must have modules') with the option to adapt peripheral elements ('menu modules'). Haueter (1983) was the first to develop this concept of core elements. Thompson and Merrilees (2001) apply this modular concept to three international retail franchise cases: McDonald's (US), Cash Converters and CarLovers (both Australian). Through these case studies, the authors make a case for the applicability of this modular approach to international franchise research, regardless of the franchising system's origin. They argue that all franchisors contemplating internationalizing into emerging markets could benefit from having a system containing these three modular sub-systems -- marketing, branding and operations. Each sub-system requires a "core" and also needs to contain "menu elements." The host country's culture is cited by the authors as a critical element for successful franchise development. Emerging markets are heterogeneous rather than homogenous in nature. The authors believe that culture itself will determine the way in which menu items are determined because of this heterogeneity. They call for further research to include these key concepts in model development.

\section{Practice and Theory Development}

Authors have also examined why retail franchising has had such an impact internationally and what forms retail franchising has taken in different parts of the world. Grimaldi (1992) analyzed the opportunities for retail franchising in free trade zones. Kaufmann (2001) inspected issues of cultural and legal differences 
in the age of the Internet and the impact of retail franchising on host country development. Specifically, he investigated already proven concepts in retail franchising, modes of entry, cultural and legal differences, host country development and technological advances. The purpose of the paper was to begin examining the benefits and costs of international business format franchising from the perspective of three major constituencies -- the host country government, the local franchisee, and the international franchisor. Integral to this discussion was the adaptability of the franchise systems to the various cultures, legal frameworks and economic issues in developing countries.

Stanworth, Price and Purdy (2001) deemed retail franchising as a means of technology-transfer for developing economies. Their article explored the background inherent in the internationalization of retail franchising, including favorable factors to growth, benefits to developing economies, other consequences to developing economies, advantages and risks to franchisors, as well as government action to encourage retail franchising. The authors recognized factors that are favorable to the growth of retail franchising as growing urbanization, rising disposable incomes and expanding consumer markets. The benefits to developing countries were identified as managerial, marketing and consumer know-how.

Other consequences to developing countries with the entry of retail franchising were cultural homogeneity by exposure to Western tastes, loss of economic diversity, possible displacement of existing local businesses, repatriation of fees and profits, and notions of control from a distance. 
Government action to encourage retail franchising was cited as the relaxation of legislation to allow foreign ownership, and conformity with international codes of copyright protections, trademark rights and other forms of intellectual property. The authors conferred special insight into Indonesia, China, and Brazil. The authors used the example of Indonesia and China to illustrate the government's action to encourage retail franchising. The paper closes with the call for development of models, theory and research in emerging franchise markets.

\section{World Market Areas}

The table in Appendix 1 summarizes international retail franchising articles by world market, year published, title of article and author(s). These articles are reviewed below.

\section{(Insert Table 1 about here)}

Central and Eastern Europe. Nitin Sanghavi's (2001) article, "The Use of Franchising as a Tool for SME Development in Developing Economies: A Case of Central European Economics," gave his personal perspective on the use of retail franchising as an economic development tool from his numerous experiences with those countries. He summarized the current state of retail franchising in Eastern Europe as compared to 1997 when he first looked at the topic (Sanghavi 1997). 
Swerdlow, Roehl, and Welsh (2001), and Alon and Banai (2001) in their respective articles, "Hospitality Franchising in Russia for the $21{ }^{\text {st }}$ Century: Issues, Strategies, and Challenges," and "Franchising Opportunities and Threats in Russia," gave us a historical review of franchise development in Russia, as well as a current and future look at the prospects for retail franchise development in an area of the world that is barely realizing its full potential as an economic power. Both articles examined the post-communist economy with a focus on environmental factors associated with international retail franchise development and entry strategies those potential franchisors would find successful. The articles included some practical suggestions for those entering and maneuvering through this huge market. Skip Swerdlow and Dianne Welsh, along with co-authors, published a number of articles in the early 1990s examining franchising in the former U.S.S.R. that are summarized in the aforementioned article (Swerdlow and Bushmarin 1994; Welsh and Swerdlow 1991,1993). Christy and Haftel also summarized the early Russian market place in a 1992 article. The next year (1993), these authors published the only case study on franchising in Russia in the early era, Pizza Hut entering the Moscow market. Today's Russia is much different, both politically and economically. Anttonen and his colleagues (2005) provide an up-to-date examination of the opportunities and threats in the Russian franchising market. Despite much of the liberalization, many obstacles remain in the market.

Aneta Nedialkova (2001) specifically examined franchising opportunities in Bulgaria, with a focus on the macroeconomic factors of the Bulgarian economy 
associated with retail franchising. While international investors have been developing franchises in Bulgaria for over twenty-five years, the market has remained sluggish, given the government system and bureaucracy. However, the article described a number of positive elements and success stories that gave reasons to be optimistic concerning the future of retail franchise development in Bulgaria.

Ljiljana Viducic (2001) described the two types of franchise arrangements that are prevalent in Croatia, using the examples of McDonald's and Diner's Club. Primarily, retail franchising has taken the form of several corporate facilities in operation, where local interaction with the store is limited to employment, not ownership. The second form, where an entrepreneur is taken on as a franchise holder with the understanding that his capital involvement will increase over time as well as his ownership interest as a full franchisee. Additionally, the article elaborated on the current state of Croatian franchise activity and other forms of market expansion that have been successful in Croatia.

Pavlin (2001) empirically analyzed the current condition of Slovenian franchising. Using the definition of franchising adopted by the European Franchise Federation, there are currently over 40 operating franchise systems in Slovenia. He compared these results to studies he conducted on Slovenian franchising that were published in 1998 and 2000. In 1998, there were 40 franchises operating in his country, of which 20 participated in his survey on the current state of franchising. The article included results from a recent survey of prospective Slovenian franchisees, identifying their core attributes and offering a 
framework for profitable future development of the franchise industry in Slovenia.

Mexico and South America. Three articles focus on different aspects of Mexican franchising. Teegan (2001) examined foreign expansion and market entry from three different perspectives. The first perspective is the Mexican franchisee that might purchase the rights to an U.S. based franchise. The second perspective is the U.S. franchisor that might sell the rights to their business format. The third perspective is the host government, namely Mexico, in terms of the economic impact and development within their country. The author shared the results of a survey of over 70 Mexican franchisees of U.S. based franchise systems. Results showed that the commonly held beliefs within both the United States and Mexico concerning the desirability of retail franchising as a mode of market entry, and that caution on the part of franchisees, franchisors, and the host governments is warranted. The article gives a realistic view of the risks and rewards of retail franchising and a bountiful amount of information for those contemplating retail franchising in Mexico.

Hadjimarcou and Barnes (2001) explained the expansion process of a relatively new and small franchisor, Silver Streak Restaurant Corporation, into Mexico in a case study. Silver Streak Restaurant Corporation originally opened their first franchised restaurant in 1996 in Juarez, a city of 1.5 million on the border of the United States (Hadjimarcou and Barnes 1998). The authors explained the cultural challenges of entering Mexico, the company's efforts to identify a suitable partner in the host country, the adaptation of the concept to 
address differences in the new market, and the multitude of crucial decisions that must be made when going international. The authors discussed the recent changes in the law that favor franchising, as well as the role that strategic alliances played in the success of their international franchise efforts. Implications for both research and practitioners are explicated.

Welsh (2001) updated a study conducted by Falbe and Welsh in 1988 that was the first to examine the effect, if any, of the North American Free Trade Agreement (NAFTA) on franchisor perceptions of characteristics associated with franchisee success and failure in Canada, Mexico, and the United States. The original research addressed two key issues in franchising. First, was to examine the extent of the franchisee study's success and failure by analyzing franchise executives' perceptions of the importance of a number of characteristics associated with franchisee success and failure. Second, was to examine differences among the executives' perceptions of these characteristics based on the location of the franchisor -- Canada, Mexico, or the United States. Their study found that the respondents' perceptions of the importance of system quality, brand name, local environment and communication, and other scales of franchisor and franchisee activities, differed by country of origin. Additionally, the study's results displayed that neither business type nor franchise size had any effect on perceptions of success or failure. Welsh examined the research that has been conducted since the study appeared in 1998 and what was known as of 2001. In a similar study, Lafontaine and Oxley (2000) found that the majority of US and Canadian franchisors employed the same contract terms in Mexico as in their 
home market. Their study reported the operations of more than 200 US and Canadian franchisors in Mexico.

Josias and McIntyre published the first article examining franchising in Brazil during 1995. In 2001, McIntyre gave us an update on what is now the third largest franchising market in the world. Only the United States and Canada have more franchises than Brazil. The author covers the history of franchising in Brazil, describing what is unique about Brazilian franchising, and giving her view of the country's prospects for the future franchise market. McIntyre views Brazilian franchising as ripe for development, evidenced by the size of the domestic franchise industry, demographics of the population, and current economic conditions.

Asia. Researchers began publishing articles on franchising in Asia during 1995. McCosker (1996) reported on a survey of foreign franchises that desired to enter into the Asian markets of Singapore, Malaysia, Hong Kong, and Indonesia. He gathered information from the existing literature as well as franchisors that had already entered these markets and interviews during visits to those countries. Chan, Foo, Quek, and Justis (1994) published an article that reported on a survey that identified the major franchises that existed, the different types of franchises, and the nature and characteristics of franchise agreements in Singapore. Subsequent to an earlier study that examined franchising in East Asia, in general (1990), Goh and Lee (1996) surveyed 62 franchisors in Singapore. They assessed the state of retail franchise development as well as franchise fee structures, the prevalence of homegrown franchises, and the effect of the government's efforts to 
promote franchising. Chiou, Hsieh and Yang (2004) examined franchisee satisfaction and intention to remain in the franchise system in Taiwan. In 1995, Chan and Justis looked at franchising in Indonesia by investigating the climate for franchising and the perceptions of the Indonesian people toward franchising.

English and Xau (1994) explored franchising in China by reporting on the entrance into and subsequent experiences of two US-based franchises in that country: Kentucky Fried Chicken (KFC) and McDonald's. Recent relations between the US and China have been anything but warm, however, the Chinese still love the retail franchising concept. In April of 2001, when a US surveillance plane went down on Chinese soil, there was still a block-long line on a rainy evening to dine at Pizza Hut. There are 326 McDonalds, as well as several Starbucks Coffee, Kenny Rogers Roasters, Pizza Hut, and KFC franchises, among others, that were showing no sign of slow sales (Friess 2001). Not unlike Russia, China also changed markedly in the last number of years and the conditions vary by industry. Alon and his colleagues $(2002,2005)$ provide a review of the restaurant and professional services, respectively.

Other Areas. Franchising around the globe has been explored in a number of other emerging market countries, including India (Paswan and Dant 1995), Kuwait (Welsh, Raven, and Al-Bisher 1996), and South Africa (Scholtz 1996, 1997). Paswan and Dant (1995) published an exploratory study of franchising in India that looked at the definition of franchising and its meaning in the American markets as compared to the Indian markets. The authors also included a framework for understanding the franchise industry internationally. 
Kuwait is explored from a case study perspective of a Mercedes Benz retail franchise dealing with a shoplifter of spare parts (Welsh, Raven, and Al-Bisher 1996). Scholtz in his 1996 and subsequent 1997 articles, described the state and penetration of franchising as a form of business in South Africa. He included an

overview of the environment for franchising, the population, and the legal regulations concerning franchising. In 1997, he reported that there were 170 franchise systems and 6,000 outlets operating in the country and that the market was ripe for more entry of international retail franchises.

\section{Conclusion}

We have attempted to summarize and explain the current state of research in the area of emerging franchise markets worldwide. We accomplished this by discussing the nature and scope of emerging markets, then summarizing the research both from a theoretical and practical development perspective as well as by specific franchise studies by region of the world. In doing so, we hoped to have raised the level of understanding among franchisors, franchisees, franchise associations, consultants, and academics concerning franchising around the globe. To our knowledge, this is the first attempt at summarizing the research on a global basis, from both a practitioner as well as an academic viewpoint.

Emerging markets are becoming more important as opportunities for retail franchising in the US diminish because of market saturation and increased competition. Many of the industries in which franchising prevails are mature and 
offer little economic profits in developed markets. Such industries include fast food, retailing, hotel and motels, and other service-based businesses.

On the other hand, emerging markets prefer markets that are unsaturated, poised for growth, and have pent-up demand for products and services embodying international standards and quality. Franchising allows local entrepreneurs to own and operate outlets that belong to multinational companies and that have well-known brand name awareness. Kodak Express outlets in China are a case in point. These outlets, owned and operated by Chinese entrepreneurs, distribute a variety of image-based internationally known products to local consumers in 50 cities around China. There are currently more then 5000 such outlets operating in China alone (Alon, 2001).

\section{Future Research}

We hope this furthers the discussion of franchising in emerging markets, and leads to a more comprehensive development of the international field of retail franchising. In particular, theory development as well as thorough empirical research needs to be conducted on all aspects of franchising in emerging markets. Consideration should be given to the role of government in the franchise relationship. How this varies from country to country and region to region needs to be examined, as well as the climate toward the host country franchise and the culture of the country and region.

Future research should also concentrate on the role of information technology in franchising globally and the positive and negative aspects of the 
information age in franchising. For example, the Internet is a great way to disseminate training information worldwide but may also have the negative effect of no personal contact to exchange vital information between the franchisee and the franchisor, such as cultural norms and behaviors that are better understood on a personal basis.

More research is also needed to identify the determinants of the modes of entry available for international retail franchisors. While there are many types of international retail franchising permutations, such as licensing, area franchising, master franchising, direct franchising etc., little research is available to explain why and how franchisors have used various modes of entry in penetrating emerging markets. Master international retail franchising, joint ventures, and wholly owned subsidiaries have all been used as methods of entering emerging markets. Master international retail franchising seems to be the preferred mode by many small and medium sized franchisors.

The need for adaptation vs. standardization needs to be explored further in emerging markets. While standardization allows a franchisor to ensure consistent quality which lead to brand awareness, emerging markets are often so different that significant modifications in operations or format of the original system are sorely needed. This area is ripe for research, as international retail franchising in emerging markets will continue to increase. Further model development needs to occur. We hope that this article will stimulate additional discussion and debate both in academic circles and by international retail franchising practitioners who seek a greater understanding of their global environment. 



\section{References}

Alon, Ilan and Ke Bian (2005), "Real Estate Franchising: The Case of Coldwell Banker Expansion into China," Business Horizons, 48 (3), 223-231.

Alon, Ilan (2004), "Global Franchising and Development in Emerging and Transitioning Markets," Journal of Macromarketing, 24 (2), 156167.

Alon, Ilan, Mark Toncar, and Lu Le (2002), "American Franchising Competitiveness in China," Journal of Global Competitiveness, 10 (1), 65-83.

Alon, Ilan (2001). "International Franchising in China: An Interview with Kodak," Proceedings of the International Society of Franchising. Minneapolis, Minn.: University of St. Thomas Institute for Franchise Management.

Alon, Ilan (1999). The Internationalization of U.S. Franchising Systems. New York, New York: Garland Publishing.

Alon, Ilan, and Moshe Banai (2001). "Franchising Opportunities and Threats in Russia," in International Franchising in Emerging Markets: Central and Eastern Europe and Latin America. Eds. Dianne H.B. Welsh and Ilan Alon. Chicago, Ill.: CCH, Inc., 131148.

Alon, Ilan, and David I. McKee (1999). "Towards a Macro-Environmental Model of International Franchising," Multinational Business Review 7(1), 76-82.

Amies, Michael (1999). "The Wilder Shores of Franchising," Franchising World, 27-28.

Anttonen, Noora, Mika Tuunanen, Ilan Alon (2005), “The International Business Environments of Franchising in Russia," Academy of Marketing Science Review, (5), 1-18.

Arnold, David J., and John A. Quelch (1988). "New Strategies in Emerging Markets," Sloan Management Review 40(1), 7-20.

Boyle, Emily (1999). "A Study of the Impact of Environment Uncertainty on Franchise Systems: The Case of Petrol Retailing in the UK," Journal of Consumer Marketing 16(2), 181-195. 
Brickley, James A. and Frederick Dark (1987). "The Choice of Organizational Form: The Case of Franchising," Journal of Financial Economics 18 (June): 401-420.

Brehaus, Brian (1998). "Risky Business?", Restaurant Business (November 1), 35-42.

Chan, Peng S., John K.S. Foo, George Quek, and Robert T. Justis (1994). "A Survey of Franchising in Singapore," Proceedings of the International Society of Franchising. Minneapolis, Minn.: University of St. Thomas Institute for Franchise Management.

Chan, Peng S., and Robert T. Justis (1990). "Franchise Management in East Asia," Academy of Management Executive 4(2), 75-85.

Chan, Peng S., and Robert T. Justis (1995). "Franchising in Indonesia," Proceedings of the International Society of Franchising. Minneapolis, Minn.: University of St. Thomas Institute for Franchise Management.

Chiou, Jyh-Shen, Chia-Hung Hsieh and Ching-Hsien Yang (2004). "The Effect of Franchisors' Communication, Service Assistance, and Competitive Advantage on Franchisees' Intentions to Remain in the Franchise System." Journal of Small Business Management 42(1) 19-36.

Christy, Ronald, and Sandra M. Haftel (1992). "Franchising Entry and Developmental Strategies in the Former Soviet Union," Proceedings of the International Society of Franchising. Minneapolis, Minn.: University of St. Thomas Institute for Franchise Management.

Christy, Ronald, and Sandra M. Haftel (1993). "Pizza Hut in Moscow: Post-Coup System Development and Expansion," Proceedings of the International Society of Franchising. Minneapolis, Minn.: University of St. Thomas Institute for Franchise Management.

Clarke, Greg. (1997). Buying Your First Franchise, $2^{\text {nd }}$ ed., London, England: Kogan Page.

Coase, Ronald H. (1937). "The Nature of the Firm," Economica 4 (November): 386-405.

Connell, John (1999). "Diversity in Large Firm International Franchise Strategy," Journal of Consumer Marketing 16(1), 86-95. 
Czinkota, Michael R., and Ilkka A. Ronkainen (1997). "International Business and Trade in the Next Decade: Report from a Delphi Study," Journal of International Business Studies 28(4), 827-844.

Dana, Leo Paul, Hamid Etemad, and Richard W. Wright (2001). "Franchising in Emerging Markets: Symbiotic Interdependence within Marketing Networks," in International Franchising in Emerging Markets: Central and Eastern Europe and Latin America. Eds. Dianne H.B. Welsh and Ilan Alon. Chicago, Ill.: CCH, Inc., 119-129.

Doherty, Anne Marie, and Barry Quinn (1999). "International Retail Franchising: An Agency Theory Perspective," International Journal of Retail and Distribution Management 27(6), 224-236.

Elango, Balasubramanian, and Vance A. Fried (1997). "Franchise Research: A Literature Review and Synthesis," Journal of Small Business Management 35(3), 68-81.

English, Wilke, and Chin Xau (1994). "Franchising in China: A Look at KFC and McDonald's," Proceedings of the International Society of Franchising. Minneapolis, Minn.: University of St. Thomas Institute for Franchise Management.

Etemad, Hamid; Richard W. Wright, and Leo Paul Dana (2001). "Symbiotic International Business Networks: Collaboration between Small and Large Firms," Thunderbird International Business Review 43(4), 281-301.

Falbe, Cecilia M., and Dianne H.B. Welsh (1998). "NAFTA and Franchising: A Comparison of Franchisor Perceptions of Characteristics Associated with Franchisee Success and Failure in Canada, Mexico, and the United States," Journal of Business Venturing 13(2), 151-171.

Friess, Steve (2001, April 18). "Despite Friction, Harsh Words, US-China Are Bound Together," USA Today 19(151), 8A.

Goh, Mark, and Heng Lee (1996). "Local Franchising Development in Singapore," Franchising Research: An International Journal 1(3), 8-20.

Grimaldi, Antonio (1992). "Franchising Opportunities in the Free Trade Zones of Developing Countries," Proceedings of the International 
Society of Franchising. Minneapolis, Minn.: University of St. Thomas Institute for Franchise Management.

Hackett, Donald W. (1976). "The International Expansion of US Franchise Systems: Status and Strategies," Journal of International Business Studies 7(1), 65-75.

Hadjimarcou, John, and John W. Barnes (1998). "Case Study: Strategic Alliances in International Franchising- the Entry of Silver Streak Restaurant Corporation into Mexico," Journal of Consumer Marketing 15(6), 598-607.

Hadjimarcou, John, and John W. Barnes. (2001). "Strategic Alliances in International Franchising: The Entry of Silver Streak Restaurant Corporation into Mexico," in International Franchising in Emerging Markets: Central and Eastern Europe and Latin America. Eds. Dianne H.B. Welsh and Ilan Alon. Chicago, Ill.: CCH, Inc., 293-306.

Haueter, Edward. (1983). "Organizing for International Marketing," Vital Speeches of the Day, 49(20), 620-624.

Hoffman, Richard and John Preble (2003) "Convert to Compete: Competitive Advantage through Conversion Franchising." Journal of Small Business Management, 41(2), 187-204.

International Franchise Research Centre. (2000). "World Wide Franchising Statistics", Available (IFRC Web Site) http:// www.wmin.ac.uk/ purdyd/

Josias, Allen, and Faye S. McIntyre (1995). "Franchising in Brazil," Proceedings of the International Society of Franchising. Minneapolis, Minn.: University of St. Thomas Institute for Franchise Management.

Justis, Robert T., Warren Nielson, and Sang J. Yoo (1988). "Franchising in Asia," Proceedings of the International Society of Franchising. Minneapolis, Minn.: University of St. Thomas Institute for Franchise Management.

Kaufmann, Patrick J. (2001). "International Business Format Franchising and Retail Entrepreneurship: A Possible Source of Retail KnowHow for Developing Countries-Post-Script," in International Franchising in Emerging Markets: Central and Eastern Europe and Latin America. Eds. Dianne H.B. Welsh and Ilan Alon. Chicago, Ill.: CCH, Inc., 80-85. 
Kaufmann, Patrick J. and Harvey Leibenstein (1988). "International Business Format Franchising and Retail Entrepreneurship: A Possible Source of Retail Know-How for Developing Countries," Journal of Development Planning 18, 165-179.

Lafontaine, Francine, and Joanne Oxley (2000). "International Franchising: Evidence from US and Canadian Franchisors in Mexico," Proceedings of the International Society of Franchising. Minneapolis, Minn..: University of St. Thomas Institute for Franchise Management.

Mathewson, G. Frank and Ralph Winter (1985). The Economics of Franchise Contracts," Journal of Law and Economics 28 (October): 503-526.

McCosker, Colin F. (1996). "Franchising into Asia: An Overview of Selected Target Markets," Proceedings of the International Society of Franchising. Minneapolis, Minn.: University of St. Thomas Institute for Franchise Management.

McIntyre, Faye S. (2001). "World-Class Franchising: The Case of Brazil," in International Franchising in Emerging Markets: Central and Eastern Europe and Latin America. Eds. Dianne H.B. Welsh and Ilan Alon. Chicago, Ill.: CCH, Inc., 223-232.

Milbank, Dana. (2001, April 21). "Protesters Disrupt Summit on Trade," Washington Post,124 (137), A1, A16.

Nair, S.R. (2001). "Franchising Opportunities in China from the Perspective of a Franchisee," in International Franchising in Emerging Markets: China, India, and other Asian Countries. Eds. Ilan Alon and Dianne H.B. Welsh. Chicago, Ill.: CCH, Inc., 109121.

Nedialkova, Aneta A. (2001). "Bulgaria-Economic Development and Franchising," in International Franchising in Emerging Markets: Central and Eastern Europe and Latin America. Eds. Dianne H.B. Welsh and Ilan Alon. Chicago, Ill.: CCH, Inc., 203-214.

Norton, Seth W. (1988). "An Empirical Look at Franchising as an Organizational Form," Journal of Business 61 (2): 197-218.

Paswan, Audhesh K., and Rajiv P. Dant (1995). "Franchising in India: An Introduction", Proceedings of the International Society of 
Franchising. Minneapolis, Minn.: University of St. Thomas Institute for Franchise Management.

Pavlin, Igor (1998). "Franchising in Slovenia: Support to the Development of Franchise Systems in Central Europe," Proceedings of the International Society of Franchising. Minneapolis, Minn.: University of St. Thomas Institute for Franchise Management.

Pavlin, Igor (2000). "New Trends in Slovenian franchising," Proceedings of the International Society of Franchising. Minneapolis, Minn.: University of St. Thomas Institute for Franchise Management.

Pavlin, Igor (2001). "Central Europe: Franchising in Slovenia," in International Franchising in Emerging Markets: Central and Eastern Europe and Latin America. Eds. Dianne H.B. Welsh and Ilan Alon. Chicago, Ill.: CCH, Inc., 189-201.

Rubin, Paul (1978). "The Theory of the Firm and the Structure of the Franchise Contract," Journal of Law and Economics 21 (April): 223-233.

Sanghavi, Nitin (1997). "Franchising as a Tool for SME Development in Transitional Economies: The Case of Central European Countries," Proceedings of the International Society of Franchising. Minneapolis, Minn.: University of St. Thomas Institute for Franchise Management.

Scholtz, Gert J. (1996). "Franchising in South Africa," Proceedings of the International Society of Franchising. Minneapolis, Minn.: University of St. Thomas Institute for Franchise Management.

Scholtz, Gert J. (1997). "An Overview of South African Franchising," Franchising Research: An International Journal 2 (4), 145-151.

Stanworth, John, and David Purdy (2001). "Franchising as a Source of Technology Transfer to Developing Countries," International Franchising in Emerging Markets: Central and Eastern Europe and Latin America. Eds. Dianne H.B. Welsh and Ilan Alon. Chicago, Ill.: CCH, Inc., 87-103.

Swartz, Leonard N. (2001). "Franchising Successfully Circles the Globe," in International Franchising in Emerging Markets: Central and Eastern Europe and Latin America. Eds. Dianne H.B. Welsh and Ilan Alon. Chicago, Ill.: CCH, Inc., 43-61. 
Swerdlow, Skip and Nicholas Bushamarin (1994). "Does Business Format Management Master Marxism in Post-Coup Russia? Franchise System Mentality Creeps into the Lodging Industry," Proceedings of the International Society of Franchising. Minneapolis, Minn.: University of St. Thomas Institute for Franchise Management.

Swerdlow, Skip, Wesley S. Roehl, and Dianne H.B. Welsh (2001). "Hospitality Franchising in Russia for the $21^{\text {st }}$ Century: Issues, Strategies, and Challenges," in International Franchising in Emerging Markets: Central and Eastern Europe and Latin America. Eds. Dianne H.B. Welsh and Ilan Alon. Chicago, Ill.: CCH, Inc., 149-170.

Swerdlow, Skip and Dianne H.B. Welsh (1992). "The Future of Franchising in the U.S.S.R.: A Statistical Analysis of the Opinions of Soviet University Students," Proceedings of the International Society of Franchising. Minneapolis, Minn.: University of St. Thomas Institute for Franchise Management.

Teegan, Hildy (2001). "Strategic and Economic Development Implications of Globalizing through Franchising: Evidence from the Case of Mexico," in International Franchising in Emerging Markets: Central and Eastern Europe and Latin America. Eds. Dianne H.B. Welsh and Ilan Alon. Chicago, Ill.: CCH, Inc., 265-292.

Thompson, Megan, and Bill Merrilees (2001). "A Modular Approach to Branding and Operations for International Franchising Systems in Emerging Markets," in International Franchising in Emerging Markets: Central and Eastern Europe and Latin America. Eds. Dianne H.B. Welsh and Ilan Alon. Chicago, Ill.: CCH, Inc., 105118.

Viducic, Ljiljana and Gordana Brcic (2001). "The Role of Franchising in Establishing and Internationalization of Business with Special Reference to Croatia," in International Franchising in Emerging Markets: Central and Eastern Europe and Latin America. Eds. Dianne H.B. Welsh and Ilan Alon. Chicago, Ill.: CCH, Inc., 215222.

Welch, Lawrence S. (1989). "Diffusion of Franchise Systems Use in International Operations," International Marketing Review 6(5), 719. 
Welsh, Dianne H.B. (2001). "NAFTA and Franchising: A Post-Script," in International Franchising in Emerging Markets: Central and Eastern Europe and Latin America. Eds Dianne H.B. Welsh and Ilan Alon. Chicago, Ill: $\mathrm{CCH}$, Inc.

Welsh, Dianne H.B. and Cecilia M. Falbe (2001). "Multiple Uses of the Internet in Franchising," Symposium presented at the $15^{\text {th }}$ Conference of the International Society of Franchising, Las Vegas, Nev.

Welsh, Dianne H.B., Peter Raven, and Faisel Al-Bisher (1996). "The Case of the Elegant Shoplifter, Shuwaikh, Kuwait," Franchising Research: An International Journal 11(3), 43-45.

Welsh, Dianne H.B., and Skip Swerdlow (1991). "Opportunities and Challenges for Franchisors in the U.S.S.R.: Preliminary Results of a Survey of Soviet University Students," Proceedings of the International Society of Franchising. Minneapolis, Minn.: University of St. Thomas Institute for Franchise Management

Welsh, Dianne H.B., and Skip Swerdlow (1993). "A Cross-Cultural Study of American and Russian Hotel Employees: A Preliminary Review and Its Implications for Franchisors," Proceedings of the International Society of Franchising. Minneapolis, Minn.: University of St. Thomas Institute for Franchise Management.

Willems, Jo, Wilke English, and Victor Ito (1992). "Pizzas in Mexico? Si!," Proceedings of the International Society of Franchising. Minneapolis, Minn.: University of St. Thomas Institute for Franchise Management

Young, Joyce A., Faye S. McIntryre, and Robert D. Green (2000). "The International Society of Franchising Proceedings: A Thirteen-Year Review," Proceedings of the International Society of Franchising. Minneapolis, Minn.: University of St. Thomas Institute for Franchise 


\section{Appendix 1}

\section{Table 1}

Summary of U.S. Published Articles on Franchising in Emerging Markets*

\begin{tabular}{|c|c|c|}
\hline Year & Title & Author(s) \\
\hline 1988 & Franchising in Asia & $\begin{array}{l}\text { Justis, Neilson } \\
\text { and Yoo }\end{array}$ \\
\hline 1988 & $\begin{array}{l}\text { International business format franchising and retail entrepreneurship: } \\
\text { A possible source of retail know-how for developing countries: }\end{array}$ & $\begin{array}{l}\text { Kaufmann and } \\
\text { Leibenstein }\end{array}$ \\
\hline 1990 & Franchise management in East Asia & Chan and Justis \\
\hline 1991 & Opportunities and challenges for franchisors in the U.S.S.R.: & $\begin{array}{l}\text { Welsh and } \\
\text { Swerdlow }\end{array}$ \\
\hline & Preliminary results of a survey of Soviet university students & \\
\hline 1992 & $\begin{array}{l}\text { The future of franchising in the U.S.S.R.: } \\
\text { A statistical analysis of the opinions of Soviet university students }\end{array}$ & $\begin{array}{l}\text { Swerdlow and } \\
\text { Welsh }\end{array}$ \\
\hline 1992 & $\begin{array}{l}\text { Franchising opportunities in the free trade zones } \\
\text { of developing countries }\end{array}$ & Grimaldi \\
\hline 1992 & Pizzas in Mexico? Si! & $\begin{array}{l}\text { Willems, English, } \\
\text { and Ito }\end{array}$ \\
\hline 1992 & $\begin{array}{l}\text { Franchising entry and developmental strategies in } \\
\text { the former Soviet Union }\end{array}$ & Christy and Haftel \\
\hline 1993 & $\begin{array}{l}\text { Pizza Hut in Moscow: } \\
\text { Post-coup system development and expansion }\end{array}$ & Christy and Haftel \\
\hline 1993 & $\begin{array}{l}\text { A cross cultural study of American and Russian hotel employees: } \\
\text { A preliminary review and its implications for franchisors }\end{array}$ & $\begin{array}{l}\text { Welsh and } \\
\text { Swerdlow }\end{array}$ \\
\hline 1994 & A survey of franchising in Singapore & $\begin{array}{l}\text { Chan, Foo, Quek, } \\
\text { and Justis }\end{array}$ \\
\hline 1994 & Franchising in China: A look at KFC and McDonald's & English and Xau \\
\hline 1994 & $\begin{array}{l}\text { Does business format management master Marxism } \\
\text { in post-coup Russia? }\end{array}$ & $\begin{array}{l}\text { Swerdlow and } \\
\text { Bushmarin }\end{array}$ \\
\hline 1995 & Franchising in Brazil & $\begin{array}{l}\text { Josias and } \\
\text { McIntryre }\end{array}$ \\
\hline 1995 & Franchising in India: An introduction & Paswan and Dant \\
\hline
\end{tabular}


1996 Franchising into Asia: An overview of selected target markets McCosker

1996 Local franchising development in Singapore

1996 The case of the elegant shoplifter, Shuwaikh, Kuwait

1997 Franchising as a tool for SME development in transitional economies: The case of Central European countries

1997 An overview of South African franchising

1998 NAFTA and franchising: A comparison of franchisor perceptions of characteristics associated with franchisee success and failure in Canada, Mexico, and the United States

1998 Franchising in Slovenia: Support to the development of franchise systems in Central Europe

1998 Case Study: Strategic alliances in international franchising-the entry of Silver Streak Restaurant Corporation into Mexico

$2000 \quad$ New trends in Slovenian franchising

2000 International franchising: Evidence from US and Canadian franchisors in Mexico

2001 International Franchising in China: An Interview with Kodak

2002 American Franchising Competitiveness in China Toncar and
Goh and Lee

Welsh, Raven, and Al-Bisher

Sanghavi

Scholtz

Falbe and Welsh

Pavlin

Hadjimarcou and Barnes

Pavlin

Lafontaine and Oxley

Alon

Alon,

$\mathrm{Lu}$

Anttonen, Tuunanen and 
* The authors do not intend for this list to be comprehensive Note. For a complete citation, see the Reference list. 